\title{
Pengaruh Pemberian Ubi Jalar Ungu terhadap Peningkatan Kadar Haemoglobin Pada Ibu Hamil Trimester III
}

\author{
$\underline{\text { Elisa Ulfiana }{ }^{1} \text { Farida Amalia Yuliandani }{ }^{2} \text { Retno Kusuma Dewi }{ }^{3} \text { Wilujeng Kartika Ratri }{ }^{4}}$ \\ ${ }^{1}$ Lecturer Poltekkes Kemenkes Semarang \\ 2,3, 4 Students of Midwifery Applied Bachelors Study Program Poltekkes Kemenkes Semarang
}

Corresponding author: Elisa Ulfiana

Email : my_ulep@yahoo.com

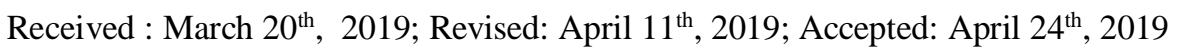

\begin{abstract}
Maternal Mortality Ratio is an important indicator to determine the degree of public health. causes of maternal death in Indonesia is the most common cause of obstetric direct and indirect maternal deaths due to hemorrhage, eclampsia, complications of abortion, sepsis postpartum, obstructed, including anemia (Depkes RI, 2009). According to data from the Genuk public health center in 2014 the number of hemoglobin levels pregnant women examined 303 people with anemia pregnant women 131 votes (43.23\%), while in 2015 the number of hemoglobin levels pregnant women examined 721 people with anemia pregnant women 358 votes $(49.65 \%)$ so that in the last 2 years an increase in maternal anemia (PHC profile Genuk, 2015).The purpose of this study was to determine the effect of giving sweet potato consumption to hemoglobin levels in third trimester pregnant women. This study uses quasi experiments. The population of this study were TM III pregnant women at the Genuk Health Center, Semarang City using total sampling technique. The results showed that the consumption of sweet potatoes influential to increase the hemoglobin level of pregnant women was indicated by $p$ value 0,000 .Expected that midwives can improve health services, especially to overcome anemia in pregnant women by providing health education about the benefits of sweet potatoes as an alternative food ingredient that can increase maternal hemoglobin levels and prevent anemia. Midwives can also encourage pregnant women to consume other food sources one of them is by consuming sweet potatoes
\end{abstract}

Keyword: Sweet potatos; anemia; hemoglobin; pregnancy.

\section{Pendahuluan}

Angka Kematian Ibu (AKI) merupakan salah satu indikator yang penting untuk menentukan derajat kesehatan masyarakat, AKI menggambarkan jumlah wanita yang meninggal dari suatu penyebab kematian terkait dengan gangguan kehamilan atau penanganannya (tidak termasuk kecelakaan atau kasus insidentil) selama kehamilan, melahirkan dan dalam masa nifas (42 hari setelah melahirkan) tanpa memperhitungkan lama kehamilan per 100.000 kelahiran hidup. AKI digunakan untuk pemantauan kematian terkait dengan kehamilan.Indikator ini dipengaruhi status kesehatan secara umum (Dinkes Kota Semarang, 2014).

Menurut Survei Demografi Kesehatan Indonesia (SDKI) tahun 2007 dan tahun 2012 menunjukkan bahwa terdapat peningkatan Angka Kematian Ibu (AKI) dari 228 menjadi 359 per 100.000 kelahiran hidup (Kemenkes RI, 2015). penyebab kematian ibu yang paling umum di Indonesia adalah penyebab obstetric langsung seperti komplikasi pada kehamilan, persalinan dan nifas yang tidak tertangani dengan baik dan tepat waktu, sedangkan secara tidak langsung kematian ibu disebabkan oleh perdarahan, eklampsia, komplikasi aborsi, sepsis pasca persalinan, partus macet, termasuk anemia (Depkes RI, 2009). terdapat beberapa kondisi lainnya seperti Anemia pada penduduk usia 15 - 24 tahun masih tinggi yaitu sebesar 18,4\% (Riskesdas, 2013); perkawinan usia dini masih tinggi yaitu sebesar 46,7\% (Riskesdas, 2010); angka kelahiran pada usia remaja juga masih tinggi yaitu sebesar 48 per 1.000 perempuan pada usia $15-19$ tahun (SDKI, 2012).

Angka kejadian anemia di Indonesia dalam kehamilan cukup tinggi. Berdasarkan hasil Riset Kesehatan Dasar (Riskesdas) tahun 2013, Kota Semarang tahun 2013 jumlah ibu hamil 1702 orang yang mengalami anemia 444 orang (26\%), dan 
tahun 2014 jumlah ibu hamil 1167 orang yang mengalami anemia 403 orang (35\%) dan pada tahun 2015 jumlah ibu hamil 21.057 orang, yang mengalami anemia 3861 orang $(18,33 \%)$ (Dinkes Kota Semarang, 2015).

Berdasarkan sumber data yang diperoleh dari Puskesmas Genuk Kota Semarang pada tahun 2013 jumlah ibu hamil yang diperiksa Hbnya 209 orang dengan jumlah ibu hamil yang anemia 78 orang $(37,3 \%)$, pada tahun 2014 jumlah ibu hamil yang diperiksa Hbnya 303 orang dengan jumlah ibu hamil anemia 131 orang $(43,23 \%)$, sedangkan pada tahun 2015 jumlah ibu hamil yang diperiksa $\mathrm{Hb} 721$ orang dengan jumlah ibu hamil yang anemia 358 orang $(49,65 \%)$ sehingga dalam 3 tahun terakhir di Puskesmas Genuk terjadi kenaikan jumlah ibu hamil yang mengalami anemia yaitu pada tahun 2014 terjadi kenaikan sebesar 5,93\% dan pada tahun 2015 terjadi kenaikan lagi sebesar 6,42\% (Profil Puskesmas Genuk, 2015).

Menurut WHO, 40\% kematian ibu di negara berkembang berkaitan dengan anemia dalam kehamilan. Anemia dalam kehamilan adalah kondisi ibu dengan kadar haemoglobin $(\mathrm{Hb})$ dibawah 11 gr\% pada trimester I dan III atau kadar $<10,5$ gr\% pada trimester II (Saifuddin, 2002).

Anemia defisiensi besi pada ibu dapat mempengaruhi pertumbuhan dan perkembangan janin atau bayi saat kehamilan maupun setelahnya (Kemenkes RI, 2015).Terjadinya anemia pada masa kehamilan karena volume darah total ibu meningkat sekitar 30-50\% pada kehamilan tunggal dan $50 \%$ pada kehamilan kembar. Volume darah total merupakan kombinasi volume plasma yang meningkat $70 \%$ dan volume sel darah merah yang juga meningkat $33 \%$ dari nilai sebelum hamil semua ini menyebabkan hemodilusi yang telihat pada kadar hematocrit rendah yang dikenal dengan anemia fisiologis pada kehamilan dan sering terjadi pada usia kehamilan 24-32 minggu. Peningkatan volume darah total dimulai pada awal trimester pertama yang kemudian meningkat pesat hingga pertengahan kehamilan dan kemudian melambat hingga menjelang minggu ke 32 (Varney, 2007).

Perubahan hemodinamik memudahkan sistem kardiovaskuler pada ibu memenuhi kebutuhan janin sambil mempertahankan status kardiovaskulernya sediri. Perubahan-perubahan ini disebabkan oleh peningkatan kadar estrogen, progesterone, dan prostaglandin, dan perubahan ini akan kembali normal setelah kehamilan berakhir (Varney, 2007).
Pencegahan dan pengobatan anemia dapat ditentukan dengan memperhatikan faktor-faktor penyebabnya, jika penyebabnya adalah masalah nutrisi, penilaian status gizi dibutuhkan untuk mengidentifikasi nutrient yang berperan dalam kasus anemia.Anemia gizi dapat disebabkan oleh berbagai macam nutrient penting pada pembentukan hemoglobin.Defisiensi $\mathrm{Fe}$ yang umum terjadi di dunia merupakan penyebab utama terjadinya anemia gizi (Fatmah, 2011).

Kurangnya zat besi dalam makanan dapat mengakibatkan anemia.(Proverawati dan asfuah, 2009) sehingga ekstra zat besi diperlukan pada kehamilan. Kebutuhan zat besi pada kehamilan dengan janin tunggal adalah 200-600 mg untuk memenuhi peningkatan massa sel darah merah; 200-370 mg untuk janin yang bergantung pada berat lahirnya; 150-200 mg untuk kehilangan eksternal; 30-170 mg untuk tali pusat dan plasenta; 90-310 mg untuk menggantikan darah yang hilang saat melahirkan, sehingga untuk mengatasi kehilangan ini, ibu hamil memerlukan rata-rata 3,5-4 mg zat besi per hari (Jordan, 2003).

Pemberian zat besi pada ibu hamil merupakan salah satu syarat pelayanan kesehatan pada ibu hamil untuk mencegah terjadinya anemia, dimana jumlah suplemen zat besi yang diberikan selama kehamilan ialah sebanyak 90 tablet $\left(\mathrm{Fe}^{3+}\right)$. Zat besi merupakan mineral yang dibutuhkan tubuh untuk membentuk sel darah merah (hemoglobin), pembentukan sel darah merah, zat besi juga berperan sebagai salah satu komponen dalam membentuk mioglobin (protein yang membawa oksigen ke otot), kolagen (protein yang terdapat pada tulang, tulang rawan, dan jaringan penyambung), serta enzim. Zat besi juga berfungsi dalam sistem pertahanan tubuh (Kemenkes RI, 2015).

Ubi jalar (Ipomoea Batatas) adalah salah satu tanaman herbal yang tumbuh menjalar didalam tanah dan menghasilkan umbi (Murtiningsih, 2011). Dari tahun 1960-an penanaman ubi jalar sudah meluas hampir di semua provinsi di Indonesia. Pada tahun 1968, Indonesia merupakan Negara penghasil ubi jalar nomor empat terbesar di dunia karena berbagai daerah menanam ubi jalar (Rukmana, 2002).

Soenardi pada tahun 2009 mengatakan bahwa ubi jalar salah satu palawija yang potensial dikembangkan untuk penganekaragaman konsumsi pangan dan merupakan jenis umbi yang relative tahan disimpan, semakin lama disimpan rasanya bertambah manis. Sifat kimiawi dan efek farmakologis ubi jalar manis, dingin, astringent. 
Ubi jalar memiliki nilai gizi yang tinggi, kaya vitamin, dan mineral. Dalam seratus gram ubi jalar terkandung energi (123 kkal), protein (2,7 g), lemak $(0.79 \mathrm{~g})$, mineral kalsium $(30 \mathrm{mg})$, fosfor (49 mg), besi (4 mg), vitamin B-1 $(0.09 \mathrm{mg})$, vitamin B-2 $(0.32 \mathrm{mg})$, vitamin C (2-20 mg), dan air $(68,5 \%)$. Kandungan lemak dalam ubi jalar cukup rendah (Toruan, 2012).

Macam macam umbi berdasakan warna umbinya (Murtiningsih, 2011) yaitu, ada ubi jalar warna ungu, oranye, kuning, dan putih. Keunggulan lain ubi jalar adalah warna dagingnya yang beraneka ragam menunjukkan komponen bioaktif serta rasanya. Daging umbi yang berwarna kuning, oranye hingga jingga menunjukkan adanya beta-karoten yang berfungsi sebagai vitamin A didalam tubuh manusia (Soenardi, 2009).

Ubi jalar mengandung $4 \mathrm{mg}$ zat besi dalam 100 gram (Toruan, 2012), sehingga penggunaan ubi jalar dapat dikonsumsi ibu hamil yaitu dapat meningkatkan kadar hemoglobin dalam sel darah merah, dapat mencegah dan mengobati anemia karena kaya akan zat besi.

Tujuan penelitian ini untuk mengetahui pengaruh pemberian konsumsi ubi jalar terhadap kadar hemoglobin pada ibu hamil trimester III.

\section{Metode Penelitian}

Penelitian ini menggunakan pendekatan kuantitatif, metode yang digunakan dalam penelitian ini adalah quasi experiment atau eksperimen semu.Desain yang digunakan dalam penelitian ini Pretest-Postest Design with Kontrol Group.Teknik sampling dalam penelitian ini adalah Purposive sampling.Populasi penelitian ini adalah ibu hamil TM III di Puskesmas Genuk, Kota Semarangdengan menggunakan teknik total sampling dengan jumlah responden sebanyak 44 responden yang terbagi menjadi 2 kelompok. Alat yang digunakan untuk mengumpulkan data dalam penelitian ini menggunakan alat pengukur hemoglobin digitalmini screen dengan merek Hospitex.Alat yang digunakan untuk mengumpulkan data dalam penelitian ini adalah $\mathrm{Hb}$ digital yang digunakan untuk mengukur kadar hemoglobin sebelum dan sesudah diberikan ubi jalar.

\section{Hasil dan Pembahasan}

Tabel 1

Distribusi frekuensi kadar hemoglobin ibu hamil sebelum diberikan intervensi pada kelompok intervensi dan kontrol.

\begin{tabular}{ccccc}
\hline & n & Mean & SD & $\begin{array}{c}\text { Min- } \\
\text { Maks }\end{array}$ \\
\hline Intevensi & 22 & 10.8545 & 0.6638 & $10-12.5$ \\
\hline Kontrol & 22 & 10.4636 & 0.6835 & $9.2-11.7$ \\
\hline
\end{tabular}

Hasil penelitian menunjukkan kadar hemoglobin ibu hamil sebelum diberikan intervensi pada kelompok intervensi rata-rata 10.8545 dan pada kelompok kontrol rata-rata 10.4636, dengan kejadian anemia sebelum mengkonsumsi ubi jalar sebagian besar mengalami anemia ringan dan sesudah mengkonsumsi ubi jalar menjadi normal.

Berdasarkan hasil rata-rata kadar hemoglobin ibu hamil menunjukkan bahwa ratarata kadar hemoglobin ibu hamil dibawah $11 \mathrm{gr} \%$ yang artinya ibu hamil mengalami anemia ringan. Ibu hamil dinyatakan anemia jika hemoglobin $(\mathrm{Hb})$ $<11 \mathrm{mg} / \mathrm{L}$ (Kemenkes RI, 2015).

Anemia pada kehamilan yang disebabkan kekurangan zat besi mencapai kurang lebih $95 \%$. Terjadinya peningkatan volume darah mengakibatkan hemodilusi atau pengenceran darah sehingga kadar $\mathrm{Hb}$ mengalami penurunan dan terjadi anemia. (Varney, 2007).Anemia defisiensi besi pada ibu dapat mempengaruhi pertumbuhan dan perkembangan janin atau bayi saat kehamilan maupun setelahnya (Kemenkes RI, 2015).

Penyebab Anemia Pada Ibu Hamil adalah meningkatnya jumlah kebutuhan zat besi guna pertumbuhan janin bayi yang dikandungnya. Penyebab anemia pada ibu hamil adalah makanan yang kurang bergizi, gangguan pencernaan dan malabsorbsi, kurang zat besi dalam makanan, kebutuhan zat besi yang meningkat, kehilangan darah banyak seperti persalinan yang lalu, haid dan lain-lain, serta penyakit-penyakit kronik seperti TBC, paru, cacing usus, malaria dan lain-lain. Anemia pada ibu hamil dapat mengakibatkan persalinan premature, perdarahan antepartum, gangguan pertumbuhan janin dalam rahim, asphyxia intrauterine sampai kematian, BBLR, gestosis dan mudah terkena infeksi, IQ rendah, dekompensatio kardis-kematian ibu (Proverawati dan Asfuah, 2009). 
Tabel 2

Distribusi frekuensi kadar hemoglobin ibu hamil setelah diberikan intervensi pada kelompok intervensi dan kontrol.

\begin{tabular}{ccccc}
\hline & $\mathbf{n}$ & Mean & SD & Min-Maks \\
\hline $\begin{array}{c}\text { Inter- } \\
\text { vensi }\end{array}$ & 22 & 11.4318 & 0.6854 & $10.0-12.8$ \\
\hline $\begin{array}{c}\text { Kon- } \\
\text { trol }\end{array}$ & 22 & 10.6455 & 0.6602 & $9.4-11,8$ \\
\hline
\end{tabular}

Hasil penelitian menunjukkan bahwa kadar hemoglobin ibu hamil sesudah diberikan intervensi pada kelompok intervensi rata-rata 11,4318 dan pada kelompok kontrol rata-rata 10,6455 , dengan kejadian anemia sebelum mengkonsumsi tablet fe sebagian besar mengalami anemia ringan dan sesudah mengkonsumsi tablet fe tetap anemia ringan.

Menurut Fatmah (2011) pencegahan dan pengobatan anemia dapat ditentukan dengan memperhatikan faktor-faktor penyebabnya, jika penyebabnya adalah masalah nutrisi, penilaian status gizi dibutuhkan untuk mengidentifikasi nutrient yang berperan dalam kasus anemia. Anemia gizi dapat disebabkan oleh berbagai macam nutrient penting pada pembentukan hemoglobin.

Zat besi menurut Wijayakusuma (2008) diperlukan dalam pembentukan hemoglobin, sehingga jika tubuh kekurangan zat besi maka akan menghambat pembentukan hemoglobin. Akibatnya, pembentukan sel darah merah terhambat sehingga mengakibatkan anemia.Cara mengatasi kekurangan zat besi pada tubuh menurut Tarwoto \& Wasnidar (2013) dengan cara mengkonsumsi $6,3 \mathrm{mg} \mathrm{Fe}$ per hari dan meningkatkan asupan makanan sumber $\mathrm{Fe}$, menurut Wirakusumah (2007) untuk mengatasi anemia perlu konsumsi bahan-bahan pangan sumber zat besi, diantaranya daging, hati, ikan, susu, yoghurt, kacang-kacangan, serta sayuran berwarna hijau, tetapi sumber makanan dari tanaman herbal juga banyak mengandung zat besi yang bermanfaat untuk mengatasi anemia.

Bagi wanita hamil harus dilakukan screening pada kunjungan ANC dan rutin pada setiap trimester (Fatmah, 2011).Ekstra zat besi diperlukan pada kehamilan. Kebutuhan zat besi pada kehamilan dengan janin tunggal adalah 200-600 mg untuk memenuhi peningkatan massa sel darah merah; 200-370 mg untuk janin yang bergantung pada berat lahirnya; 150-200 mg untuk kehilangan eksternal; 30-170 mg untuk tali pusat dan plasenta;
90-310 mg untuk menggantikan darah yang hilang saat melahirkan, sehingga untuk mengatasi kehilangan ini, ibu hamil memerlukan rata-rata 3,5-4 $\mathrm{mg}$ zat besi per hari (Jordan, 2003).Pemberian Ubi Jalar pada kelompok intervensi menunjukkan rata-rata adanya peningkatan kadar hemoglobin karena Ubi Jalar mempunyai kandungan zat besi sehingga bisa mencegah anemia atau kekurangan darah. Ubi Jalar dapat meningkatkan kadar hemoglobin karena menurut Toruan (2012) Ubi Jalar mempunyai kandungan zat besi $4 \mathrm{mg}$ setiap 100 gram ubi jalar.

Tablet fe merupakan salah satu suplemen yang dapat mencegah terjadinya anemia, karena menurut Fatmah (2011) suplemen Fe adalah salah satu strategi untuk meningkatkan intake Fe yang berhasil hanya jika individu mematuhi aturan konsumsinya.

Pemberian ubi jalar pada kelompok intervensi menunjukkan rata-rata adanya peningkatan kadar hemoglobin karena menurut Toruan (2012) Ubi Jalar mempunyai kandungan zat besi $4 \mathrm{mg}$ setiap 100 gram ubi jalar sehingga bisa mencegah terjadinya anemia dalam tubuh. Hal ini disebabkan karena ubi jalar mempunyai kandungan zat besi yang cukup untuk mencegah anemia atau kekurangan darah.

Pemberian tablet Fe pada kelompok kontrol menunjukkan bahwa peningkatan kadar hemoglobin rata-rata adalah $0,18 \mathrm{gr} / \mathrm{dl}$, sehingga konsumsi tablet $\mathrm{Fe}$ saja belum cukup untuk meningkatkan kadar hemoglobin secara signifikan sehingga diperlukan makanan tambahan lain untuk membantu meningkatkan kadar hemoglobin, salah satunya dengan mengkomsumsi ubi jalar.

Hasil penelitian yang menunjukkan tidak ada perbedaan kadar hemoglobin ibu hamil sebelum dan sesudah diberikan intervensi pada kelompok kontrol dengan hanya menggunakan konsumsi tablet $\mathrm{Fe}$ saja dapat disebabkan karena faktor lain yang menurut Waryono (2010) dapat disebabkan karena faktor gizi ibu hamil yang kurang dari kebutuhan, serta faktor penghambat penyerapan tablet besi seperti cara minum yang salah. 
Tabel 3

Pengaruh Pemberian Konsumsi Ubi Jalar Terhadap Kadar Hemoglobin pada Ibu Hamil Trimester III.

\begin{tabular}{cccc}
\hline & Kelompok & n & $\begin{array}{c}\text { P value uji } \\
\text { beda }\end{array}$ \\
\hline $\begin{array}{c}\text { kadar } \\
\text { hemoglobin } \\
\text { ibu hamil } \\
\text { sesudah } \\
\text { diberikan } \\
\text { intervensi }\end{array}$ & Intervensi & 22 & 0,000 \\
\cline { 2 - 4 } & Kontrol & 22 & 0,078 \\
\hline
\end{tabular}

Berdasarkan hasil analisis data menunjukkan bahwa bahwa hasil uji analisis data dengan uji wilcoxondengan hasil $p$ value pada kelompok intervensi adalah 0,000 yang artinya ada perbedaan kadar hemoglobin ibu hamil sebelum dan sesudah diberikan intervensi pada kelompok intervensi dan pada kelompok kontrol adalah 0,078 yang artinya tidak ada perbedaan kadar hemoglobin ibu hamil sebelum dan sesudah diberikan intervensi pada kelompok kontrol.

Ubi jalar memiliki kandungan karbohidrat yang tinggi sehingga membuat ubi jalar dapat dijadikan sumber kalori. Selain itu kandungan karbohidrat ubi jalar tergolong Low Glycemix Index (LGI 54) yaitu tipe karbohidrat ubi jalar yang jika dikonsumsi tidak akan menaikan kadar gula darah secara drastis. Karena itu ubi jalar sangat baik jika dikonsumsi ibu hamil dengan riwayat penderita diabetes.(Murtiningsih, 2011). Ubi jalar mengandung energy sebesar (123 kkal), protein $(2,7 \mathrm{~g})$, lemak (0.79 g), mineral kalsium (30 mg), fosfor (49 mg), besi (4 mg), vitamin B-1 (0.09 mg), vitamin B-2 (0.32 mg), vitamin C (2-20 $\mathrm{mg}$ ), dan air $(68,5 \%)$. Hasil tersebut didapat dari melakukan penelitian terhadap 100 gram ubi jalar, dengan jumlah yang dapat dimakan sebanyak 100 $\%$ (Toruan, 2012).

Hemoglobin merupakan kompleks protein yang terdiri dari heme yang mengandung besi dan globin dengan interaksi di antara heme dan globin yang menyebabkan Hemoglobin $(\mathrm{Hb})$ merupakan yang ireversibel untuk mengangkut oksigen. Zat besi bersama dengan protein (globin) dan protoporfirin mempunyai peranan penting dalam pembentukan hemoglobin (Permono, 2010), sehingga jika tubuh kekurangan zat besi maka akan menghambat pembentukan hemoglobin. Proses pembentukan atau sintesis hemoglobin ini membutuhkan waktu lebih kurang $7-10$ hari hingga menjadi matang dan siap diedarkan ke seluruh tubuh dengan sel darah merah. Karena hemoglobin ini berada di dalam sel darah merah, maka masa hidupnya pun sama halnya dengan masa hidup sel darah merah, yaitu sekitar 120 hari (Guyton, 2008).

Sintesis hemoglobin dimulai dari eritoblast dan terus berlangsungsampai tingkat normoblast dan retikulosit.Penyelidikan dengan isotop diketahui bahwa bagian hem dari hemoglobin terutama disintesis dari asam asetat dan glisin dan sebagian besar sintesis ini terjadi dalam mitokondria.Langkah awal sintesis adalah pembentukan senyawa pirol.Selanjutnya, empat senyawa pirol bersatu membentuk senyawa protoporfirin, yang kemudian berikatan dengan besi membentuk molekul hem. Akhirnya empat molekul hem berikatan dengan satu molekul globin, suatu globulin yang disintesis dalam ribosom reticulum endoplasma, membentuk hemoglobin. (Guyton, 2007).

Tubuh sangat efisien dalam penggunaan besi. Sebelum di absorpsi, di dalam lambung besi dibebaskan dari ikatan organik, seperti protein. Sebagian besar besi dalam bentuk ferri direduksi menjadi bentuk ferro. Hal ini terjadi dalam suasana asam di dalam lambung dengan adanya $\mathrm{HCl}$ dan vitamin $\mathrm{C}$ yang terdapat di dalam makanan (Almatsier, 2004).

Absorpsi terutama terjadi di bagian atas usus halus (duodenum) dengan bantuan alat angkut protein khusus. Ada dua jenis alat angkut protein di dalam sel mukosa usus halus yang membantu penyerapan besi, yaitu transferin dan feritin. Transferin, protein yang disintesis di dalam hati, terdapat dalam dua bentuk. Transferin mukosa mengangkut besi dari saluran cerna ke dalam sel mukosa dan memindahkannya ke transferin reseptor yang ada di dalam sel mukosa. Transferin mukosa kemudian kembali ke rongga saluran cerna untuk mengikat besi lain, sedangkan transferin reseptor mengangkut besi melalui darah ke semua jaringan tubuh. Dua ion ferri diikatkan pada transferin untuk dibawa ke jaringan- jaringan tubuh. Banyaknya reseptor transferin yang terdapat pada membran sel bergantung pada kebutuhan tiap sel. Kekurangan besi pertama dapat dilihat pada tingkat kejenuhan transferin(Almatsier, 2004).

Besi dalam makanan terdapat dalam bentuk besi-hem seperti terdapat dalam hemoglobin dan mioglobin makanan hewani (daging, hati, ikan, susu, yoghurt), dan besi non-hem dalam makanan nabati (kacang kacangan, sayuran warna hijau). Besi-hem diabsorpsi ke dalam sel mukosa sebagai kompleks porfirin utuh. Cincin porfirin di dalam sel mukosa kemudian dipecah oleh enzim khusus 
(hemoksigenase) dan besi dibebaskan. Besi-hem dan nonhem kemudian melewati alur yang sama dan meninggalkan sel mukosa dalam bentuk yang sama dengan menggunakan alat angkut yang sama. Absorpsi besi-hem tidak banyak dipengaruhi oleh komposisi makanan dan sekresi saluran cerna serta oleh status besi seseorang. Besi-hem hanya merupakan bagian kecil dari besi yang diperoleh dari makanan (kurang lebih 5\% dari besi total makanan), terutama di Indonesia, namun yang dapat diabsorpsi dapat mencapai $25 \%$, sedangkan nonhem hanya 5\%. Agar dapat diabsorpsi, besi nonhem di dalam usus halus harus berada dalam bentuk terlarut. Besi nonhem diionisasi oleh asam lambung, direduksi menjadi bentuk ferro dan dilarutkan ke dalam cairan pelarut seperti asam askorbat, gula dan asam amino yang mengandung sulfur. Pada suasana $\mathrm{pH}$ hingga 7 di dalam duodenum, sebagian besar besi dalam bentuk ferri akan mengendap, kecuali dalam keadaan terlarut seperti disebutkan di atas. Besi fero lebih mudah larut pada $\mathrm{pH}$, oleh karna itu dapat diabsorpsi(Almatsier, 2004).

\section{Simpulan}

Kadar hemoglobin ibu hamil sebelum diberikan intervensi pada kelompok intervensi rata-rata 10.8545 dan pada kelompok kontrol ratarata 10.4636 dengan sebagian besar mengalami anemia ringan sebanyak 13 responden $(59 \%)$ dan sesudah mengkonsumsi ubi jalar menjadi normal sebanyak 18 responden $(81,9 \%)$.Kadar hemoglobin ibu hamil sesudah diberikan intervensi pada kelompok intervensi rata-rata 11,4318 dan pada kelompok kontrol rata-rata 10,6455 dengan kejadian anemia sebelum mengkonsumsi tablet fe sebagian besar mengalami anemia ringan sebanyak 15 responden $(68,2 \%)$ dan sesudah mengkonsumsi tablet fe tetap anemia ringan sebanyak 12 responden (54,5\%).Konsumsi ubi jalar berpengaruh untuk meningkatkan kadar hemoglobin ibu hamil, karena hasil penelitian menunjukkan bahwa kadar hemoglobin ibu hamil sesudah diberikan intervensi pada kelompok intervensi mengalami kenaikan kadar $\mathrm{Hb}$ sebanyak 0.58 dan pada kelompok kontrol mengalami kenaikan rata-rata sebanyak 0.18 .

Melihat hasil penelitian diatas, ada beberapa saran yang perlu disampaikan yaitu:Bagi Ibu hamil dapat menjadikan hasil peneltian ini sebagai alternative sebagai pencegah terjadinya anemia selama masa kehamilan dengan referensi bahan makanan alami yang dapat meningkatkan kadar Hemoglobin yang salah satu nya adalah ubi jalar.Bagi Pendidikan Kebidanan. Mahasiswa dapat menjadikan hasil penelitian ini sebagai sumber referensi bagi mahasiswa Pendidikan D IV kebidanan tentang penggunaan sumber makanan yang dapat meningkatkan kadar Hemoglobin yang salah satu nya adalah ubi jalar.Bagi Praktek Kebidanan. Bidan dapat memberikan pelayanan kesehatan pada ibu hamil khususnya ibu hamil anemia dengan cara memberikan pendidikan kesehatan tentang manfaat ubi jalar, sebagai salah satu bahan makanan yang dapat meningkatkan kadar hemoglobin ibu.Peneliti lain diharapkan dapat melakukan penelitian dengan memperhatikan faktor-faktor yang dapat mempengaruhi peningkatan kadar hemoglobin dan hendaknya memperhatikan atau mengendalikan variabel confounding.

\section{Daftar Pustaka}

Depkes RI. 2009. Profil Kesehatan Indonesia Tahun 2009.Jakarta : Depkes RI

Dinas Kesehatan Jawa Tengah. 2015. Profil Kesehatan Propinsi Jawa Tengah 2015. Semarang: Dinas Kesehatan Jawa Tengah.

Fatmah. (2011). Gizi dan Kesehatan Masyarakat: Anemia. Jakarta: PT. Raja Grafindo Persada.

Hidayat A.A. 2010.Metodologi Penelitian Kebidanan dan Tehnik Analisa Data.Jakarta: Salemba Medika

Guyton AC. 2007. Fisiologi Manusia dan Mekanisme Penyakit. Jakarta: PenerbitBuku Kedokteran EGC. Alih bahasa oleh Dr. Petrus Andrianto
-----------. 2008. Buku Ajar Fisiologi Kedokteran. Jakarta : EGC

Hoffbrand, A.V. dkk. 2005. Kapita Selekta Hematologi. Jakarta : EGC

Jordan. 2004. Farmakologi Kebidanan. Jakarta : EGC.

Kemenkes RI. 2015. Infodatin : Pusat Data dan Informasi Kementerian Kesehatan RI. Jakarta: Kemenkes RI.

Kristiyanasari, W. 2010.Gizi Ibu Hamil. Jogjakarta: Nuha Medika.

Lingga, Lanny. 2010. Cerdas memilih sayuran. Jakarta : Agro Media Pustaka.

Notoatmodjo. 2010. Metodologi Penelitian Kesehatan. Jakarta : Rineka Cipta.

Proverawati dan Asfuah. (2009). Gizi untuk Kebidanan. Jakarta : Nuha Medika. 
Riskesdas.(2013). Riset Kesehatan Dasar Indonesia Tahun 2013.Jakarta : Kemenkes RI.

Saryono. 2009. Metodologi Penelitian Kesehatan. Jogjakarta : Mitra Cendekia.

Sugiyono. 2007. Statistika untuk Penelitian. Bandung : Alfabeta.

Supariasa.2012. Penilaian Status Gizi.Jakarta : EGC.

Toruan. 2011.Fat-loss Not Weight-loss for Diabetes : Sakit Tapi Sehat.Jakarta : Transmedia.
Tarwoto dan Wasnidar. 2013. Buku Saku Anemia pada Ibu Hamil : Konsep dan Penatalaksanaannya. Jakarta : Trans Info Media.

Varney. 2007. Buku Ajar Asuhan Kebidanan Volume 1. Jakarta : EGC.

Yeri dan Emi. 2013. Pengaruh Mengkonsumsi Jambu Biji Merah Terhadap Peningkatan Kadar Hemoglobin Ibu Hamil Di Kelurahan Bandung Kecamatan Ngrampal,Sragen. 